\title{
Support for Progressive Taxation: Self-Interest (Rightly Understood), Ideology, and Political Sophistication
}

Journal of European Public Policy, accepted.

(C) Journal of European Public Policy

\begin{abstract}
Progressive tax rates are one of the main instruments for redistribution within advanced liberal democracies. In this study, we investigate public support for this policy. In our analysis of a novel question included in the Belgian Electoral Study (2019) we show that left-wing citizens are strongly in favour of this system. Importantly, high levels of political sophistication strengthen the association between ideology and preferences for progressive taxation, while political sophistication weakens the association between income and rejecting progressive tax policies. Support for a flat tax policy follows exactly the opposite pattern. Hence, for a highly sophisticated group apparently there is no conflict between a tax system that might hurt their short-term material interests, and support for a more equal society.
\end{abstract}

Keywords: tax rates, progressive taxes, Belgian Electoral Study, political sophistication, leftright self-placement, self-interest rightly understood 


\section{Introduction}

In an era of rising inequality in Western societies, tax policies would appear to be an effective policy instrument to achieve a higher level of redistribution among the population (Piketty 2019, ch. 17). In most countries, market incomes show a strong unequal distribution (Nolan, Salverda \& Smeeding, 2009), and governments can partly mitigate this inequality through progressive income taxing schemes and other social transfers (Guillaud, Olckers \& Zemmour, 2020). Governments, nevertheless, are typically very reluctant to change income taxation rates to address increasing inequality, fearing that higher taxation rates not only will be unpopular, but also ineffective as it is assumed that the wealthiest group has sufficient means to escape higher taxation (Mahieu, Geys \& Heyndels, 2017). Thus, even though most governments did increase redistribution efforts in recent years, it seems that these instruments are becoming less effective in reducing income inequalities (OECD, 2011).

While governments might fear that progressive taxes are not very popular, the available research does not always support this expectation (Barnes, 2015; Bernasconi, 2006; Edlund, 2003). Given the redistributive character of progressive taxes, the theoretical expectation is that when income inequality is rising, citizens will feel the need to address this problem, and will support progressive tax rates (Berens \& Gelepithis, 2019; Franko, Tolbert \& Witko, 2013; Garcia-Muniesa, 2018; Limberg, 2020). Fiscal instruments are indeed much more effective for ensuring redistribution than several social security measures, like health insurance or old age pension systems, which do not have redistribution as their primary aim (Cantillon \& Vandenbroucke, 2013). As fiscal systems tend to be rather complicated and technical, it is not self-evident whether citizens have a preference on this matter that lines up with their own preferences or their short-term material interests. The study of Bartels (2005) indeed shows that while a large group of US citizens wanted to reduce inequality, they still favoured cutting tax rates, apparently remaining oblivious to the fact that these tax cuts would further strengthen inequality within the country. This suggests that a large group of the population does not fully understand the way fiscal policy, especially the progressive nature of taxes, is related to levels of inequality. One can assume, therefore, that it requires at least some level of sophistication to match one's personal preferences and interests with the corresponding stance on the progressivity of tax rates (Bartels, 2005; Fernández-Albertos \& Kuo, 2018; Tóth \& Keller, 2011). While previous studies tend to focus on a specific determinant of preferences on tax policy, our assumption is that these effects will not be the same across all social groups. Given the inherent complexity of the fiscal system and its consequences, our hypothesis is that it 
requires at least some level of political sophistication to be able to relate one's broader set of preferences (whether they are motivated by self-interest or other considerations) to a specific policy proposal on tax policy, and this is the main contribution we would like to make to this debate. Within this article, we therefore investigate the moderating role of political sophistication in explaining citizens' support for progressive taxes, as manifest in the recent Belgian national election survey. Second, and distinct from this theoretical contribution, we also offer an empirical contribution by demonstrating how a new question wording can be used for a comprehensive measurement of tax preferences among the general public.

\section{Literature}

There can be little doubt that tax policies are one of the most important policy domains for the functioning and the stability of a political system. Tax policies are, moreover, increasingly salient, partly because they are a highly effective instrument for reducing income inequality within a society (Atkinson, 2015; OECD, 2011). Previous research has determined some important determinants of preferences on tax policy. These determinants include self-interest (i.e., those with a higher income will be less in favour of progressive taxes, or even prefer a flat tax rate), ideology (right wing citizens will favour less progressive taxes), and altruism (those who are most concerned about inequality and social exclusion will support higher tax rates for the rich) (Bechert \& Edlund, 2015; Bernasconi, 2006; Cavaillé \& Trump, 2015; Hennighausen \& Heinemann, 2015; Limberg, 2019, 2020; Newton \& Confalonieri, 1998; Roosma, van Oorschot \& Gelissen, 2016).

These studies routinely assume that these direct effects will be present in a rather uniform manner across the population, but one of the main goals of the current study is to investigate whether this is actually the case. Recent research has hinted at the fact that levels of political sophistication often moderate the association between experiences and preferences (Kim, 2019). We assume that this effect will be especially strong in the case of tax policy, first because of the technicality of fiscal regulations, and second because official government communication routinely fails to mention the redistributive effects of tax policies. While previous research has investigated the effects of income, ideology and altruism on preferences for fiscal policy, our main theoretical contribution is that we expect these effects to be moderated by the level of political sophistication. We expect this to be especially the case with preferences on proposals to introduce a flat tax rate. In these debates, it is not often mentioned 
that a flat tax rate (i.e., exactly the same tax rate for all income groups) would effectively stop the redistributive function of fiscal policy. So in this case too, we expect a strong effect of political sophistication.

\section{$\underline{\text { Self-interest }}$}

An important potential determinant of tax policy preferences is the weight of self-interest: those with a high personal income are most likely to suffer in the short run from progressive taxes and therefore should tend to be the income group less inclined to support progressive tax schemes. Further, some authors have argued strongly that preferences on taxation do not reflect an ideological position, but that these preferences are mostly determined by instrumental considerations about self-interest (Beramendi \& Rehm, 2016). Again, those with a higher income would be reluctant to support progressive taxation. More broadly, it is well-known that citizens tend to favour the public policies that they stand to benefit from (Armingeon \& Bürgisser, forthcoming; Pitlik et al., 2011), and this could also be true for fiscal policy. In that case, those with high incomes will not only be in favour of low taxation levels; they will also be less enthusiastic about the progressive character of taxation policies, and be more likely supporters of flat taxes (Bechert \& Edlund, 2015; Carroll, Dolmas \& Young, 2020; Edlund, 1999; Sumino, 2016).

\section{$\underline{\text { Ideology }}$}

Previous research has firmly established that the left-right division is associated with a specific preference for social security expenditure (Jæger, 2008), but there is less research on the relation between ideology and tax policies (Franko et al., 2013; Fernández-Albertos \& Kuo, 2018; Newton \& Confalonieri, 1998; Roosma, van Oorschot \& Gelissen, 2016). The general expectation, however, is that those who adhere to a left-wing ideology will be more strongly in favour, not only of a higher level of government intervention in the economy, but also of a more progressive tax policy.

\section{$\underline{\text { Altruism and fairness }}$}

Other authors, however, have questioned the role of self-interest and ideology in explaining preferences on fiscal policy. Using an experimental design, Ballard-Rosa et al. (2017) have shown that considerations of fairness and social justice do play an important role in determining preferences on 'taxing the rich'. Their assumption is that, regardless of personal interests and ideology, citizens also act upon notions of fairness, or even pure altruism. Experimental 
research on the perceived fairness of inheritance taxes, for instance, shows that self-interest did not matter regarding which types of tax were considered as fair (Gross, Lorek \& Richter, 2017). Similarly, research has shown that richer citizens are more in favour of redistribution when they live in more unequal countries (Beramendi \& Rehm, 2016; Berens \& von Schiller, 2017; Finseraas, 2009). Especially in times of crisis, social and political demands to 'tax the rich' will be stronger (Limberg, 2019, 2020).

\section{The role of political sophistication}

Altogether, however, these studies routinely assume that such direct effects and motivations will be present in a rather uniform manner across the population. Recent research has hinted at the fact that levels of political sophistication often moderate the relation between experiences and preferences (Kim, 2019). We assume that this effect will be especially strong in the case of tax policy, because of the technicality of fiscal regulations, and because official government communication routinely fails to mention the redistributive effects of tax policies (Bartels, 2005). Moreover, citizens' knowledge about the complex details of the fiscal system tends to be very low (Barnes et al., 2018; Bartels, 2005). Similarly, citizens typically do not know how incomes are distributed within their countries, nor do they fully appreciate the redistributive effort done by most Western governments. Furthermore, they have little knowledge about changing patterns of inequality (Gimpelson \& Treisman, 2018). Clearly, this cumulative lack of knowledge could have important repercussions for how much support they express for a progressive tax system. We might, therefore, expect that more sophisticated citizens will be more effective in determining the 'right' degree of progressiveness that is in line with their own preferences. Higher levels of political sophistication should allow citizens to better grasp the relation between their own policy preferences, and the specific tax measures that are necessary to achieve those goals (Jedinger \& Burger, 2019; Kölln, 2018).

The concept 'political sophistication' is widely used within political science research (Dassonneville, 2012; Luskin, 1990; Marthaler, 2008; Stiers, 2021). More specifically, the concept builds on the notion of a 'political belief system' (Converse, 1964; Luskin, 1987).This is the set of cognitions a voter has, and the organisation or 'constraint' of them -i.e., the extent in which they are connected and form a coherent worldview. The term 'constraint' thus refers to the cohesiveness of political opinions and attitudes. Using this concept of political sophistication, we argue that citizens with higher levels of sophistication will both (1) have a 
more coherent set of attitudes because they have a higher constraint among them, and (2) be better able to act upon their broader ideas and preferences.

First, attitudinal "constraint" was central to the early definitions of the concept of political sophistication (Campbell et al., 1964; Converse, 1964). This refers to the fact that people with higher levels of sophistication form a more coherent set of attitudes. For our purpose, this means that more sophisticated citizens will have a better understanding of which attitudes are consistent with supporting progressive taxation - i.e., constraint should lead to more attitudinal congruence. For instance, while many will agree that levels of inequality should be decreased, more sophisticated citizens will go on to link that to the idea that richer people should pay more taxes than poorer people. Lower sophisticates might not make this link, so holding an opinion less consistent with wanting to reduce levels of inequality (for instance "it is most fair to tax everyone the same"). It is hence expected that higher sophisticates will be able to engage in more complex reasoning, and that they will be more coherent and consistent in their attitudes. Therefore, for these sophisticates, we expect a stronger correlation between ideological position and their opinion on taxation. As the seminal work of Converse (1964) has shown, only a small portion of the citizenry is able to bring together various opinions in one coherent set of attitudes - and it is a sign of sophistication to be able to do so. Hence, higher sophisticates considering themselves to be left-wing, will have a coherent view on taxation (i.e., favouring more progressivity). Following the argumentation of Converse (1964), we expect lower sophisticates to be less coherent in their attitudes - as self-proclaimed left-wing citizens they could still favour less progressive taxation or even a flat tax. Taken together, the higher sophisticates should be more coherent in their ideological position and attitudes towards progressive taxation:

Hypothesis 1: Respondents with a high level of political sophistication achieve a stronger correlation between their ideological position and a position on progressive taxation.

Second, higher sophisticates can also be expected to be better able to act in line with their own interests. Higher sophisticated people will understand better how they need to act if they want to ensure a certain outcome in their favour. Research in the domain of electoral behaviour, for instance, has shown that higher sophisticates are better able to hold incumbent governments accountable for policies they deemed unsatisfactorily, incentivizing politicians to change direction in these citizens' interest in the future (de Vries \& Giger, 2014). We thus expect that 
more sophisticated citizens will be better aware of the impact of changing tax progressivity on their own situation. High sophisticates with a high income, for instance, will realize that more progressive taxation would mean that they pay more taxes - and high sophisticates with a lower income will realize they could benefit from progressive taxation.

With regard to self-interest, however, political sophistication could also have exactly the opposite effect: those with a better understanding of the function of the political system and redistribution, will realize there is a broader relevance to paying a fair level of taxes. Basically, this reflects a classic question for the well-being of democratic societies: why would those citizens who have more be willing to 'pay' for the functioning of the political system as a whole? A classic answer to this question was expressed by de Tocqueville (1840[1992]) when he wrote that even in an individualistic society like the United States, citizens are able to understand that their self-interest, rightly understood, obligates them to contribute to the common good, as they themselves are very likely to profit from a flourishing society. Wealthy groups within the population, too, benefit from a well-functioning society, even when this implies they will have to contribute individual resources; in that sense they are not altruistic, but rather have a clear grasp of how their own interests will be better advanced (Kiewiet \& Lewis-Beck, 2011). Previous research has shown that having more cognitive skills and resources is indeed associated with a better understanding of the common good, and the role of reciprocity in achieving that common good (Hooghe, Marien \& De Vroome, 2012). We assume, therefore, that some form of sophistication is indeed necessary in order to achieve insight into the formula of 'self-interest rightly understood', as de Tocqueville introduced it. This perspective, moreover, also confirms the research on how altruism plays a role in support for progressive taxation. In either case, also when it comes to ensuring their self-interest (rightly understood), we expect higher sophisticates to be more coherent.

Hypothesis 2: Respondents with a high level of political sophistication achieve a stronger correlation between their material position and a position on progressive taxation.

In order to investigate the moderating role of political sophistication, we use the results of a recent Belgian electoral survey including questions on support for progressive tax rates. In this survey, we also included a new question wording to investigate support for progressive taxes and, assuming the analysis shows clear patterns, we hope to make an empirical contribution in that regard, too. 
An important issue in the current debates on fiscal policy is the proposal for what has been called a flat tax rate, i.e., imposing exactly the same rate to all incomes, thus effectively abolishing the progressive character of income taxes. Thus far, however, there is hardly any research available on whether voters would really prefer this policy reform (Domonkos, 2016). While in various countries this kind of tax policy has been proposed, it remains to be investigated whether it has any popular support, and if so, among what groups of society. Although proponents of a 'flat rate' argue this is a fair and transparent way of taxation, the introduction of such a scheme would mean that taxes no longer have any redistributive function, and would indeed increase income inequality (Fougére \& Ruggeri, 1998; Fuest, Peichl \& Schaefer, 2008; Lyon, Dalton \& Dalton, 2018). We will therefore also investigate what kind of respondents specifically support a flat tax rate, ${ }^{1}$ whereby we expect that citizens that prefer less progressive tax rates, are also more likely to be in favour of flat taxes overall (Carroll, Dolmas \& Young, 2020). For this specific case, too, we will investigate whether political sophistication plays a moderating role. Here too, we assume, that more sophisticated citizens can be more coherent in their support towards this specific type of taxes.

Hypothesis 3: Political sophistication will moderate the effect of ideology and income on support for a flat tax rate.

\section{Data and methods}

Our analysis is based on the electoral study conducted on the occasion of the Belgian general elections being held in May 2019. Belgium is a country with elevated tax levels, as 44.8 per cent of GDP consists of taxes and social security contributions, much higher than the 34.3 per cent on average in OECD countries (OECD, 2020). The fact that we have different samples for the Dutch and the French speaking parts of the country, adds variation to the data set. The French speaking part of the country is more leftist, and Communists, Socialists and Greens jointly obtained 54.4 per cent of the vote in the 2019 regional elections. The Dutch speaking part of the country is more fiscally conservative and their left-wing parties together only obtained 25.6 per cent of the vote. Belgium offers a good case study to investigate preferences on progressive taxes. The country has one of the lowest levels of inequality among OECD countries, and following the system stability theory (Jæger, 2006) we can therefore assume that a substantial part of public opinion has interiorized the support for redistribution efforts.

\footnotetext{
${ }^{1}$ In practice, it seems that 25.3 per cent of all respondents in this Belgian study favour equal tax rates for rich and poor. From a policy perspective, then, it becomes interesting to investigate what kind of citizens support this specific kind of tax policy.
} 
Simultaneously, there is also quite a societal and political debate about fiscal policy in the country (Decoster et al., 2002). On a pragmatic level, the 2019 Electoral Survey allowed us to include a more sophisticated measurement scale for progressive taxes, a survey instrument that thus far has not been used in any other context.

\section{Dependent variable}

In the electoral survey, a novel question was included to measure respondents' taxation preferences. Traditionally, surveys ask respondents about their agreement with the statement that the government should actively reduce differences in income levels (Fernández-Albertos \& Kuo, 2018; Goubin \& Hooghe, 2020; Jæger, 2008). However, we can identify at least three problems with this standard question. First, it is not entirely clear whether respondents know what it means when they say that governments should decrease differences in income levels. Second, it is possible that respondents give different meanings to the question, as the government might take different measures to reduce income differences. Third, the measure does not allow for much detail, usually using some kind of Likert-scale ranging from "fully disagreeing" to "fully agreeing". Therefore, we use a new measure to measure tax preferences. This measure is inspired by that used by Lewis-Beck and Nadeau (2009) and Lewis-Beck, Nadeau, and Foucault (2013). In their respective studies, these authors use a measure in which respondents are asked to imagine a rich and a poor person each having a dollar, and then to consider what tax rate should be applied to each. ${ }^{2}$ Inspired by this measure, in our study, we asked respondents how much taxes a rich and a poor person should pay on every 100 euro they earn. By using these amounts, the indicated amount of taxation accords with the preferred tax rate, without any need to calculate percentages. Furthermore, instead of giving respondents fixed options to choose from, we let them decide from a full scale what their preferred tax rate for both hypothetical persons would be. More specifically, the respondents were asked the following:

This question is about taxes. Imagine that a rich and a poor person each have 100 euro on which they have to pay taxes. How much of these 100 euros should each of the pay in taxes?

\begin{tabular}{|l|l|l|l|l|l|l|l|l|l|l|l|}
\hline A rich person & 0 & 10 & 20 & 30 & 40 & 50 & 60 & 70 & 80 & 90 & 100 \\
\hline A poor person & 0 & 10 & 20 & 30 & 40 & 50 & 60 & 70 & 80 & 90 & 100 \\
\hline
\end{tabular}

\footnotetext{
${ }^{2}$ Respondents could choose from different fixed categories: (1) rich person pays 60 cents and the poor 10; (2) rich person pays 50 cents and poor 20; (3) rich person pays 40 cents and poor 30; (4) rich person pays 30 cents and poor 30; (5) don't know, not sure.
} 
We opted for this specific measurement because studies have shown that abstract questions about the "progressive nature of income tax" are often not fully understood by respondents (Roberts, Hite \& Bradley, 1994). With the measure at hand, the respondent can develop a very specific policy proposal. The variable distributions, for a rich and poor person respectively, are displayed in Figure 1.

Figure 1. Preferred tax rates for a hypothetical rich and poor person.
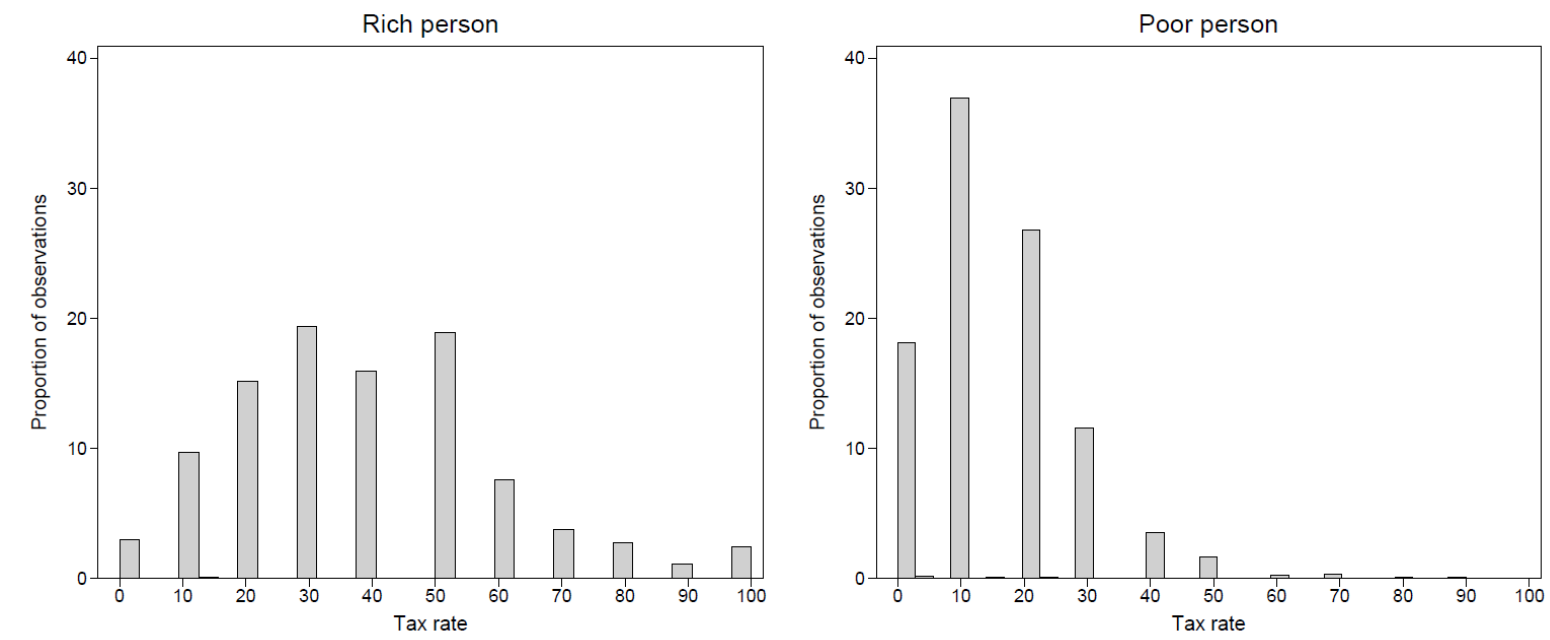

The distribution in Figure 1 shows that respondents clearly favour higher taxes for the rich. On average, respondents favour a tax rate of $38.36 \%$ (standard deviation 21.27 ) for the rich, and $15.43 \%$ (standard deviation 15.43 ) for the poor, or a difference of almost 23 percentage points. ${ }^{3}$ Furthermore, some respondents $(2.40 \%)$ prefer rich persons to pay $100 \%$ taxes and $2.96 \%$ prefer not to tax the rich at all; the maximum observed value for a poor person is $90 \%(0.11 \%)$, whereas $18.42 \%$ prefer not to tax the poor at all.

Using this scale, the dependent variable in our analyses is the distance between the preferred tax rate of the two cases, as this is a summary indicator for the degree of progressiveness preferred. ${ }^{4}$ Theoretically, this variable can range from -100 (100\% taxes for the poor, nothing

\footnotetext{
${ }^{3}$ While officially marginal tax rates in Belgium vary between 25 and 50 per cent (and these figures are also reported in international overviews), the fact that a large first income bracket is tax-exempt means that effective average tax rates indeed will vary between ca. 10 and ca. 40 percent of the total income.

${ }^{4}$ As a robustness test, we also conducted the analyses with as dependent variable the ratio of the preferred tax rate for the rich and the poor. The results, reported in Appendix B, are fully in line with the conclusions reported here, so we can be confident we are measuring a preference for progressiveness, no matter the preferred level of taxation.
} 
for the rich), to +100 (100\% taxes for the rich, nothing for the poor). The observed distribution is displayed in Figure 2.

Figure 2. Difference between preferred tax rate of a rich person and a poor person

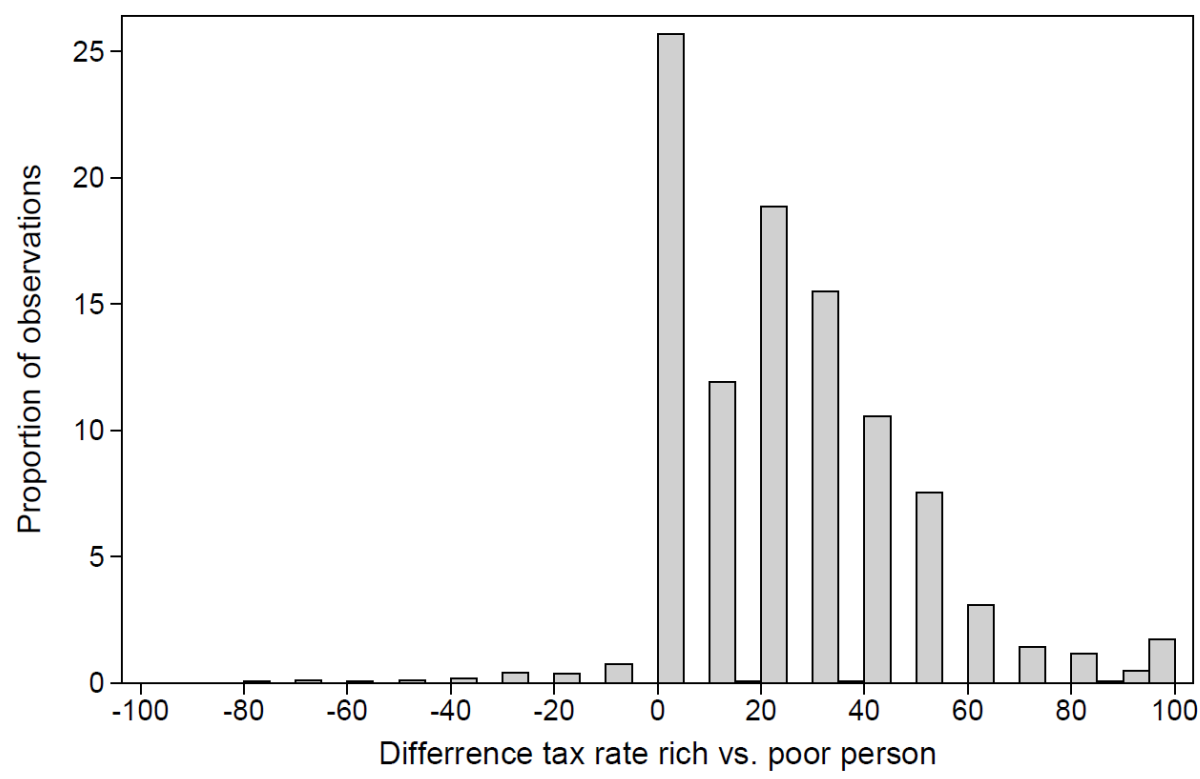

The Figure shows that there is a consensus within society that the tax rate for the rich should be at least equal, and preferably higher than for the poor. With the exception of just a few individuals ( $1.96 \%$ of all respondents), nobody suggests taxing the poor more harshly than the rich (Tarroux, 2019). There are also some interesting outliers. There are nine individuals who scored below -30 , and thus would tax the poor much harder than the rich. To handle these outliers, we chose to Winsorise these observations, using a cut-off of three standard deviations below the mean. With a mean of 22.99 and a standard deviation of 23.31, all values lower than -46.95 receive this value. On the other extreme of the scale, we have 29 respondents who would tax the rich for $100 \%$, and would have the poor not pay any taxes. As Winsorising is a symmetrical process, we also Winsorised observations scoring higher than 3 standard deviations above the mean (i.e., higher than 92.93). ${ }^{5}$

Since we use a relatively novel measure, we first test its correlation with a more traditional measure of preferences for governmental redistributive policies. We asked respondents to what extent they agreed with the statement that "the government should take measures to reduce differences in income" on a 5-point scale ranging from "fully disagree" to "fully agree" to compare whether respondents answer both questions in a similar way. Respondents agreeing

\footnotetext{
${ }^{5}$ Excluding these extreme cases altogether or keeping them in the data as they are, does not lead to substantially different results than those presented here.
} 
that the government should reduce income difference, should favour at least some level of progressive taxation. The results of this test are displayed in Figure C.1 in Appendix C. They show that, as expected, respondents agreeing with government intervention favour, on average, a higher difference in tax rate between the poor and the rich.

This comparison suggests that preferences on progressive taxes are strongly in line with broader concerns about inequality; however, the new measurement scale allows for a more comprehensive and continuous measurement of policy preferences. This is important, as there is an ongoing criticism that both the general redistribution question, as well as the left-right scale itself, are "too general", and do not reflect articulated policy preferences (Bauer et al., 2017; Iversen \& Goplerud, 2018). Fortunately, in the case at hand, we can rely on a more specific policy preference.

\section{Independent variables}

The hypotheses bring forward several independent variables of interest. First, in order to measure ideology, we use the self-placement of the respondent on the left-right scale using the traditional 0-10 continuum in which 0 signifies the most left position, 10 the most right position, and 5 the centre. Although this left-right scale has been criticised, recent research still finds it has a strong effect on the political choices on social and economic policy a citizen prefers (Dassonneville, forthcoming; Hooghe, Dassonneville \& Oser, 2019). ${ }^{6}$ Second, we measure a respondent's self-interest by means of income level and employment status. The family income of the respondent is measured with a 7-point scale (where every point denotes a range of income, starting with "less than 1000 euro/month", up to "more than 5000 euro/month" - see Appendix A).

Hypotheses 1 and 2 suppose that the associations between one's material and ideological dispositions and support for progressive taxes, will be stronger for more sophisticated voters. To test this hypothesis, we include interactions between our indicators of ideology and selfinterest respectively, and political sophistication. Political sophistication is a concept that has

\footnotetext{
${ }^{6}$ We also tested an alternative measure of ideology. More specifically, we used anti-immigration sentiments as an indicator of a cultural dimension. The results using this measure are substantially the same as those with the general left-right continuum presented here. The full results are reported in Appendix E. The fact that antiimmigrant sentiments have a similar effect as the left-right position does suggest that this dimension refers to a broader liberal or conservative orientation toward society (Kriesi et al., 2006). Furthermore, one should also consider the fact that those who are hostile toward immigration routinely assume that social security and redistribution efforts disproportionally will benefit ethnic minorities (van der Waal, de Koster \& van Oorschot, 2013).
} 
been conceptualised and operationalized in various ways (Luskin, 1987; Stiers, 2021). Traditionally, political knowledge has been argued to be the best single measure of political sophistication (Dassonneville, 2012). However, while political knowledge is best understood as a measure of cognitive abilities, Luskin (1990) has forcefully argued that there is a motivational component to sophistication as well. Therefore, in our measure of political sophistication, we include both a cognitive and motivational measure - political knowledge for the former, and political interest for the latter. ${ }^{7}$ Political knowledge was measured as the number of correct responses to four factual questions about the political system (Appendix A). Political interest was measured by asking respondents directly to what extent they are interested in politics on a 0-3-scale. As with our measure of political sophistication, we first rescale the knowledge variable to range from 0 to 3 as well to give both components equal weight, and then take these two measures together in a scale ranging from 0 to 6 .

We use age and gender as further control variables. We also include a control for those who do not participate in the labour market (students, pensioners, long-term sick, ...) as typically these groups do not pay taxes at all, or have a special provision that limits the fiscal burden on their income. As the dependent variable in our analysis is a continuous variable, we opt for an ordinary least squares (OLS) regression analysis.

\section{Results}

As a first test of the association between ideology and tax preferences, we looked at the distribution of preferred differences in taxation for left- right-wing, and centrist respondents. The results are summarised in Appendix G. Next, we estimate regression models explaining preferences for progressive taxation. First, we include indicators of ideology on the one hand and self-interest on the other. Second, we test whether the association between these indicators and preferences for progressive taxation are moderated by the respondent's level of political sophistication (Table 1).

In a first model, we investigate the direct effects of our main variables on support for progressive taxes. As expected, it shows that right wing respondents are more hostile toward progressivity. For every unit increase in ideology (on a 0-10-scale), the preferred difference in

\footnotetext{
${ }^{7}$ When we take political knowledge and political interest separately as independent variables, all direct and interaction effects go in the same direction as when using the latent concept of political sophistication. Generally, however, effects are weaker, and using political interest as a measure of sophistication, the interaction with income is not statistically significant.
} 
tax rate decreases by 1.32 percentage point. Furthermore, in line with much of the past literature, there is a negative direct effect of income (Bechert \& Edlund, 2015; Carroll, Dolmas \& Young, 2020; Sumino, 2016).

In Model 2 and Model 3, we include interactions between political sophistication and ideology and income respectively, to ascertain whether higher sophisticated respondents hold preferences that more adequately reflect their ideological position and material wellbeing. The results in model 2 are in line with our expectations, as the (negative) association between ideology and taxation preferences is stronger for higher sophisticated citizens. The main effect of ideology indicated a substantial impact of ideology on taxation preferences of more than 1.3 percentage points. The interaction effect shows that, for every unit increase in sophistication (on a 1-6-scale), the effect increases with 0.48 .

Table 1. Explaining support for Progressive Taxes

\begin{tabular}{lccc}
\hline & Model 1 & Model 2 & Model 3 \\
& B & B & B \\
& $($ s.e. $)$ & $($ s.e. $)$ & 1.427 \\
\hline Female & 1.466 & 1.389 & $(1.199)$ \\
Age & $(1.201)$ & $(1.199)$ & $0.313^{* * *}$ \\
Not in active labour force & $0.315^{* * *}$ & $0.318^{* * *}$ & $(0.044)$ \\
& $(0.044)$ & $(0.044)$ & 1.267 \\
Political sophistication & 1.234 & 1.392 & $(1.546)$ \\
& $(1.550)$ & $(1.547)$ & $-3.296^{* *}$ \\
Ideology & -0.294 & $2.143^{*}$ & $(1.179)$ \\
& $(0.460)$ & $(1.001)$ & $-1.303^{* * *}$ \\
Income & $-1.320^{* * *}$ & 0.375 & $(0.253)$ \\
Sophistication X ideology & $(0.253)$ & $(0.668)$ & $-3.809^{* * *}$ \\
Sophistication X income & $-1.195^{* *}$ & $-1.174^{* *}$ & $(1.035)$ \\
Constant & $(0.421)$ & $(0.420)$ & \\
& & $-0.480^{* *}$ & $(0.175)$ \\
\hline$N$ & & & $0.744^{* *}$ \\
$R^{2}$ & & & $(0.269)$ \\
\hline
\end{tabular}

Note: Entries are unstandardized OLS coefficients, standard errors in parentheses. Sign.: *: $<<0.05 ; * *: \mathrm{p}<0.01$; $* * *: \mathrm{p}<0.001$.

The results for income (Model 3), however, might be more surprising: the coefficient of the interaction indicates that the negative association increases when sophistication increases. To put it differently: highly sophisticated voters are less inclined to express their own short-run 
material interests. ${ }^{8}$ The main effect of income is negative and significant, indicating that, at low levels of sophistication, higher income respondents fill favour less progressive taxation in line with the self-interest hypothesis. However, the interaction shows that, for every unit increase in sophistication, the effect of income increases with 0.74 . To obtain a better view on these effects, we plot the average marginal effect of income and ideology respectively at different levels of political sophistication in Figure 3.

Figure 3. Average marginal effects of income and ideology respectively at different levels of political sophistication
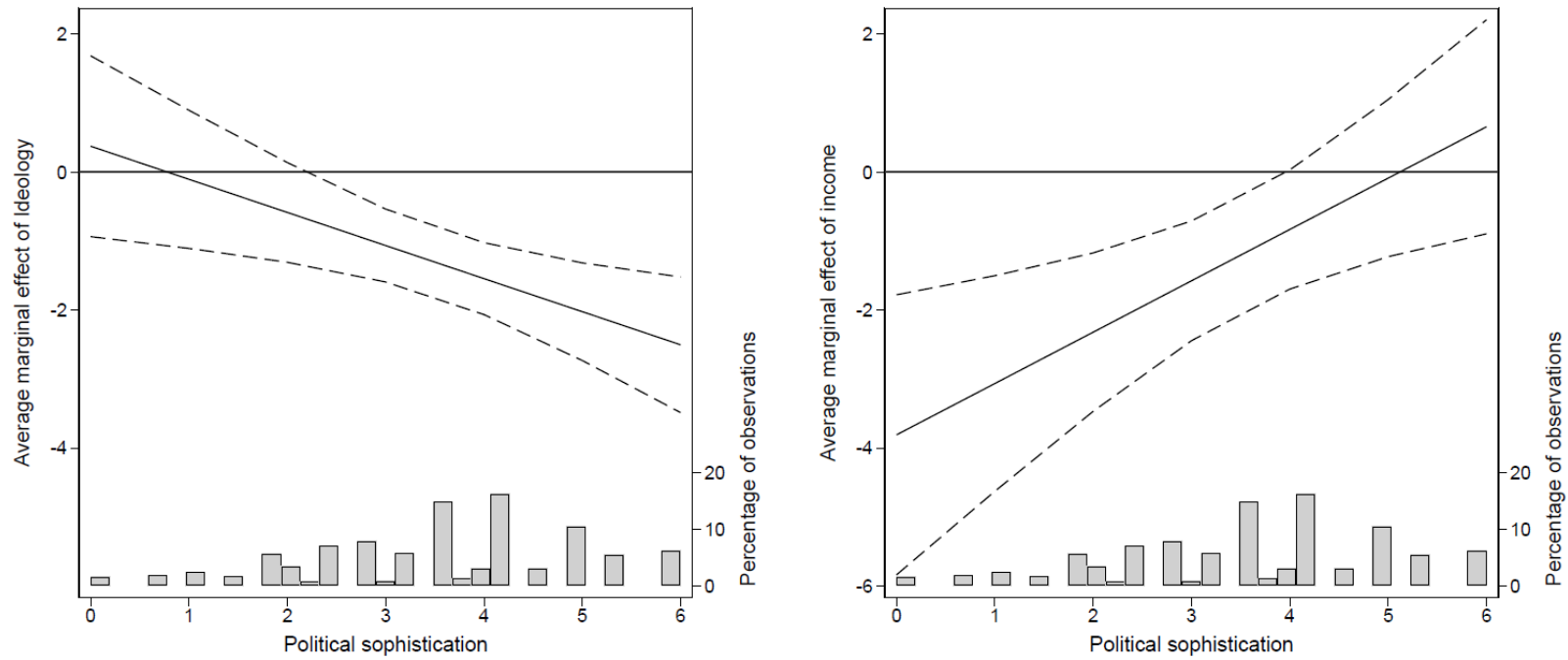

Note: Figure shows the average marginal effects of ideology (left) an income (right) on different levels of political sophistication based on the results reported in Model 3 (ideology) and Model 3 (income) in Table 1.

The figure confirms what was clear from the coefficients in Table 1. For ideology (left-hand side of Figure 3 ) the results are in line with the expectations, as there is a clear negative interaction effect: while there is no significant association between ideology and preferences for progressive taxation for the respondents that are lowest in sophistication, from some level of sophistication on there is a negative association, and the higher the level of sophistication, the larger this effect. The highly sophisticated respondents are thus better able match their ideological position with a preference for a matching policy proposal.

\footnotetext{
8 We also tested whether the objective level of inequality in the postal region where the respondent lives affects one's taxation preferences. To do so, we estimated multilevel models including an indicator of the level of inequality in the environment of the respondent. The results, reported in Appendix D, do not reveal statistically significant associations. It needs to be noted, furthermore, that the intra-class correlation only amounts to 0.002 .
} 
For income (right side of Figure 3), it can be observed that among low-sophisticated respondents, there is a clear and negative association between income and favouring progressive taxation. At higher levels of income however, this association weakens, and for the most sophisticated respondents, there is no significant association between these two indicators. ${ }^{9}$ These results indicate that mostly the least sophisticated respondents resort to defending their own short term material interests, while among the highest sophisticates there is no significant association at all. It seems that rather than acting more strongly in their own interests, sophisticates prefer the advantages of a progressive taxation system. At first sight, this seems to be in line with our hypothesis on de Tocqueville's "self-interest rightly understood". ${ }^{10}$

As these results indicate that there is a group of highly sophisticated citizens with a high income who support progressive taxes, seemingly at odds with their self-interest, it is interesting to obtain some more details about who exactly these respondents are. Therefore, we looked at the demographics of this group respondents with the highest income and highest level of sophistication, and compared this to the sample overall. The results, presented in more detail in Appendix F, show no significant differences in age, but that these respondents are mostly male, highly educated, and that they work on higher management positions. In contrast, there is no significant difference in the sector in which they work. This suggests that while this group is distinct in its education level and managerial position, they are not concentrated in a specific economic sector. We also compared the group most in favour of progressive taxes with those less in favour among the respondents with the highest income. While the former group is somewhat older than the latter, we did not find substantial differences in demographics between these two groups. Hence, it does not seem like these people's opinion are informed by their material interests - further supporting the argument of altruism and/or a broader understanding of 'self-interest' to be at play.

\footnotetext{
${ }^{9}$ One might wonder to what extent sophistication is correlated with income and ideology. In our estimation sample, the correlation between sophistication and income is 0.336, and between sophistication and ideology 0.033 . The correlation between income and ideology is 0.064 . These correlations do not lead to a multicollinearity problem. We also tested whether the ideological position of respondents who are both highly sophisticated and have a high income differ in their ideological position from those who do not, but did not find any significant nor substantial difference.

${ }^{10} \mathrm{We}$ also included several other variables in the analyses to challenge the robustness of the analyses, including occupational position, subjective social class, political trust, social trust and subjective satisfaction with welfare state services. Our main findings (direct effects and interaction effects) remain the same.
} 


\section{$\underline{\text { Support for a flat tax }}$}

In the recent past, some politicians have put forward a proposal to generalise a flat tax rate, as it is assumed that this provides more incentives for economic entrepreneurs. We do not know however, whether such a proposal has the support of public opinion. Among Belgian respondents, only a quarter of respondents supports this proposal, by assigning the same tax rate to poor and rich citizens. We code this as 'support for a flat tax rate' as ' 1 ', and all other preferences as ' 0 ', and expect to find that both more right-wing respondents and respondents with a higher income are more likely to support a flat tax - and, importantly, that this association is stronger among the higher sophisticated. The results are summarised in Table 2. ${ }^{11}$

Table 2. Support for a flat tax rate

\begin{tabular}{lccc}
\hline & Model 1 & Model 2 & Model 3 \\
& B & B & B \\
& $($ s.e. $)$ & $($ s.e. $)$ & 0.017 \\
\hline Female & 0.015 & 0.024 & $(0.120)$ \\
Age & $(0.120)$ & $(0.121)$ & $-0.017^{* * *}$ \\
Not in active labour force & $-0.017^{* * *}$ & $-0.017^{* * *}$ & $(0.004)$ \\
& $(0.004)$ & $(0.004)$ & -0.136 \\
Political sophistication & -0.136 & -0.149 & $(0.156)$ \\
& $(0.155)$ & $(0.155)$ & 0.223 \\
Ideology & -0.061 & $-0.291^{* *}$ & $(0.126)$ \\
& $(0.046)$ & $(0.107)$ & $0.129^{* * *}$ \\
Income & $0.129^{* * *}$ & -0.018 & $(0.026)$ \\
Sophistication X ideology & $(0.026)$ & $(0.067)$ & $0.273^{*}$ \\
& 0.037 & 0.035 & $(0.106)$ \\
Sophistication X income & $(0.042)$ & $(0.042)$ & \\
Constant & & $0.043^{*}$ & $(0.018)$ \\
& & & $-0.068^{*}$ \\
& & & $(0.028)$ \\
Pseudo- $R^{2}$ & & 0.135 & $-1.616^{* *}$ \\
\hline
\end{tabular}

Note: Entries are log-odds coefficients, standard errors in parentheses. Significance levels: *: $\mathrm{p}<0.05 ; * *: \mathrm{p}<0.01$; $* * *: \mathrm{p}<0.001$.

${ }^{11}$ A well-known phenomenon in survey research is that respondents who are not strongly motivated will select the same answering categories for various questions. In a separate robustness test we therefore tested whether knowledge, education level, and political interest determine the likelihood of giving twice the same answer, or not answering the question at all. The results show that the higher educated will be less likely not to answer the question. For the respondents answering the same value twice, we did not find such effects. These results support the claim that respondents supporting a flat tax are not just satisficing - although the possibility that some choose the same option twice because it is the easiest option cannot be excluded. 
The results in Table 2 indicate that, indeed, right-wing respondents seem to be more likely to support a flat tax, while we do not find a significant main effect for income. However, our hypothesis was concerned with the moderating impact of sophistication, and the interactions show a significant conditioning effect of sophistication. To get a better sense of this moderation, we again plot the average marginal effect of ideology and income respectively at different levels of sophistication in Figure 4.

Figure 4. Average marginal effects of income and ideology respectively on preferring a flat tax at different levels of political sophistication
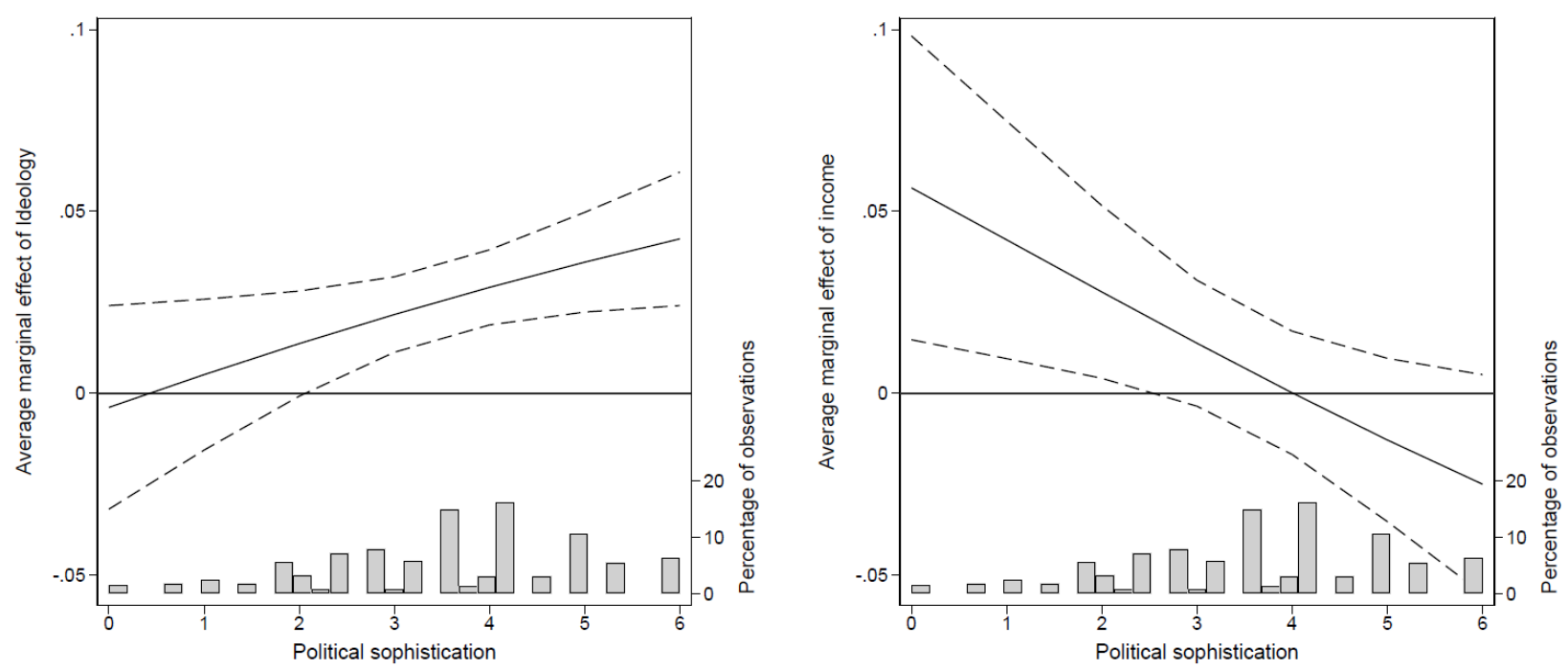

Note: Figure shows the average marginal effects of ideology (left) an income (right) on different levels of political sophistication based on the results reported in Model 3 (ideology) and Model 3 (income) in Table 2.

The left-side of Figure 4 shows that, as expected, the higher sophisticated voters are more likely to bring support for a flat tax in line with their ideological opinions. For income we again see a rather surprising finding. While, for lower sophisticates, a higher income comes with a higher likelihood to support a flat tax, this association disappears for the higher sophisticates.

\section{Conclusion}

While popular discourse often assumes that most citizens are "against" taxes, an analysis of recent Belgian survey data leads to a far more nuanced picture. First of all, a vast majority of respondents is clearly in favour of progressive taxes, and by doing so, they support a mechanism to strengthen the redistributive function of the state. Even though tax systems tend 
to be quite complex, most respondents seem to have a good idea on what kind of fiscal system they should favour. Those who say that they are left-wing, are more strongly in favour of progressive taxes, and this offers another validation of the traditional left-right scale: the position respondents give themselves predicts quite well their point of view on rather complex fiscal matters, and the more knowledgeable respondents are, the better they are able to translate their broad ideological orientation into a specific policy measure. For studies that rely on the left-right self-placement scale, it is good to know that this scale is very good in predicting the position of a respondent with regard to the progressive, and hence, redistributive character of a fiscal system. This finding is also relevant with regard to the status of left-right ideological divides. While some critics have argued that this cleavage is less relevant in contemporary society, one can observe that ideological differences account for an impressive difference in the tax rates that citizens put forward. Assuming that most citizens have strong feelings about having to pay a substantial part of their income to taxes, we can safely conclude that the leftright divide remains salient, and has substantial effects on the financial position of citizens.

One of our most surprising findings, is that the association between family income and tax preferences is positively moderated by political sophistication. At first sight, it might seem strange that among the most sophisticated respondents, the income level does not have a significant effect on their preference for progressive voting. After all, they should understand perfectly well that when taxes are not progressive, they will have to pay less. But apparently there is something that drives this group to supporting more progressive taxes. We offer two possible, and admittedly somewhat speculative explanations. First, it is possible that these highincome highly sophisticated citizens act in an altruistic manner. Second, it is equally possible that this group understands that even the rich do well in a system of relatively high taxes, as they do receive health care, low crime rates and almost free university enrolment for their children. This corresponds closely to the 'well-understood self-interest' as it was already described by" De Tocqueville, when writing about the United States:

"La doctrine de l'intérêt bien entendu n'est donc pas nouvelle; mais, chez les Américains de nos jours, elle a été universellement admise (...) ils montrent complaisamment comment l'amour éclairé d'eux-mêmes les porte sans cesse à s'aider entre eux" (de Tocqueville 1840[1992], p. 636). ${ }^{12}$

\footnotetext{
${ }^{12}$ Translation: 'The doctrine of self-interest rightly understood, clearly is not new, but among current-day Americans, she is universally accepted. They gladly show how the enlightened love for one-self, brings them to help one another constantly.'
} 
However, the insights of de Tocqueville were not completely correct. He still assumed that self-interest well-understood was a doctrine that could be shared by all: " $L$ 'intérêt bien entendu est une doctrine peu haute, mais claire et sûre (...) chacun la saisit aisément et la retient sans peine." (de Tocqueville 1840[1992], 637). ${ }^{13}$ However, we do find a strong negative relation between income and support for progressive taxes among the least sophisticated, and it is only among the most sophisticated group that their preferences are not directly related to their own short term individual advantages. However, it is important to note that these possible explanations are speculations that we cannot test here. This study results in the observation that some high-income groups favour more progressive taxation, and it is up to future research to investigate what exactly drives these people to act seemingly against their self-interest.

Sophisticated respondents furthermore are better able to connect their ideological position to their point of view with regard to the progressiveness of tax rates in a coherent manner. The strong interaction effects we observe for political sophistication should not imply that we assume a cognitive causal mechanism. We operationalised political sophistication using correct answers on a test quiz, and by using political interest. While this might imply some cognitive skills, it also refers to an orientation toward the political system and toward the social world in general. Citizens who are not interested in social and political life will typically score lower on these indicators, no matter what their level of more abstract cognitive skills might be. As these respondents are interested in, and knowledgeable about the functioning of the political system, it could be assumed that they will also be willing to contribute more resources to the system. Future research could investigate whether sophistication would play an equally important role when giving more information to respondents about the current tax system of their country and where they are located in the income distribution.

From a policy perspective, it can be noted that respondents indicate a preference for a rather high tax rate. The fact that Belgian citizens, on average, already pay a high level of taxes on income apparently does not lead to a citizens' tax revolt or backlash. The support for a flat tax rate is very limited and is concentrated among young and right-wing respondents. Most citizens seem to take the system for granted, and one could speculate that their feeling of being taxed at relatively high rates is counterbalanced by the services they receive from the state system. While most citizens of Belgium probably do not like paying taxes, when they are being asked

\footnotetext{
13 'Self-interest rightly understood might not be a very fancy doctrine, but it is clear and sure. It can easily be understood and one can keep on with it without any trouble.'
} 
to come up with their own tax system, they in fact opt for rather high, and fairly progressive tax rates - exactly in line with the regime they know today. 


\section{References}

Armingeon, K., \& Bürgisser, R. (forthcoming). Trade-offs between redistribution and environmental protection: the role of information, ideology, and self-interest. Journal of European Public Policy, in press.

Atkinson, A. (2015). Inequality. What Can Be Done? Harvard University Press.

Ballard-Rosa, C., Martin, L., \& Scheve, K. (2017). The Structure of American Income Tax Policy Preferences. Journal of Politics, 79(1), 1-16.

Barnes, L. (2015). The size and shape of government: preferences over redistributive tax policy. Socio-Economic Review, 13(1), 55-78.

Barnes, L., Feller, A., Haselswerdt, J., \& Porter, E. (2018). Information, knowledge, and attitudes: An evaluation of the taxpayer receipt. Journal of Politics, 80(2), 701-706.

Bartels, L. (2005). Homer Gets a Tax Cut: Inequality and Public Policy in the American Mind. Perspectives on Politics, 3(1), 15-31.

Bauer, P. C., Barberá, P., Ackermann, K., \& Venetz, A. (2017). Is the Left-Right Scale a Valid Measure of Ideology? Individual-Level Variation in Associations with "Left" and "Right" and Left-Right Self-Placement. Political Behavior, 39(3), 553-583.

Bechert, I., \& Edlund, J. (2015). Observing Unexpected Patterns in Cross-National Research: Blame Data, Theory, or Both? Attitudes toward Redistributive Taxation in ThirtyThree Countries. International Journal of Sociology, 45(4), 327-347.

Beramendi, P., \& Rehm, P. (2016). Who Gives, Who Gains? Progressivity and Preferences. Comparative Political Studies, 49(4), 529-563.

Berens, S., \& von Schiller, A. (2017). Taxing Higher Incomes: What Makes the High-Income Earners Consent to More Progressive Taxation in Latin America? Political Behavior, 39(3), 703-729.

Berens, S., \& Gelepithis, M. (2019). Welfare state structure, inequality, and public attitudes towards progressive taxation. Socio-Economic Review, 17(4), 823-850.

Bernasconi, M. (2006). Redistributive taxation in democracies: Evidence on people's satisfaction. European Journal of Political Economy, 22(4), 809-837.

Cantillon, B., \& Vandenbroucke, F. (eds., 2013). Reconciling Work and Poverty Reduction. How Successful Are European Welfare States? Oxford: Oxford University Press.

Carroll, D.R., Dolmas, J., \& Young, E.R. (2020). The Politics of Flat Taxes. Review of Economic Dynamics, in press.

Campbell, A., Converse, P.E., Miller, W.E. (1964). The American Voter: An Abridgement. New York: Wiley. 
Cavaillé, C. \& Trump, K. (2015). The Two Facets of Social Policy Preferences. Journal of Politics, 77(1), 146-160.

Converse, P.E. (1964). The Nature of Belief Systems in Mass Publics. In D.E. Apter (ed.), Ideology and Discontent (pp. 206-261). New York: Free Press.

Dassonneville, R. (2012). Electoral Volatility, Political Sophistication, Trust and Efficacy: A Study on Changes in Voter Preferences During the Belgian Regional Elections of 2009. Acta Politica, 47(1), 18-41.

Dassonneville, R. (forthcoming). Change and continuity in the ideological gender gap. A longitudinal analysis of left-right self-placement in OECD countries. European Journal of Political Research, in press.

Decoster, A., Standaert, I., Valenduc, C., Van Camp, G. (2002). What makes personal income taxes progressive? The case of Belgium. Brussels Economic Review, 45(3), 91-112.

De Tocqueville, A. (1840[1992]). De la Démocratie en Amérique, t. II. Paris : Gallimard (Bibliothèque de la Pléiade, vol. 385).

De Vries, C. A., \& Giger, N. (2014). Holding Governments Accountable? Individual Heterogeneity in Performance Voting. European Journal of Political Research, 53(2), $345-362$.

Domonkos, S. (2016). Who Wants a Progressive Income Tax?: Determinants of Tax Policy Preferences in Post-socialist Eastern Europe. East European Politics and Societies, $30(2), 423-448$.

Edlund, J. (1999). Attitudes towards Tax Reform and Progressive Taxation: Sweden 1991-96. Acta Sociologica, 42(4), 337-355.

Edlund, J. (2003). Attitudes towards taxation: Ignorant and incoherent? Scandinavian Political Studies, 26(2), 145-167.

Fernández-Albertos, J., \& Kuo, A. (2018). Income Perception, Information, and Progressive Taxation: Evidence from a Survey Experiment. Political Science Research and Methods, 6(1), 83-110.

Finseraas, H. (2009). Income inequality and demand for redistribution: A multilevel analysis of European public opinion. Scandinavian Political Studies, 32(1), 94-119.

Franko, W., Tolbert, C., \& Witko, C. (2013). Inequality, Self-Interest, and Public Support for “Robin Hood” Tax Policies. Political Research Quarterly, 66(4), 923-937.

Fougére, M., \& Ruggeri, G.C. (1998). Flat Taxes and Distributional Justice. Review of Social Economy, 56(3), 277-294. 
Fuest, C., Peichl, A., \& Schaefer, T. (2008). Is a flat tax reform feasible in a grown-up democracy of Western Europe? A simulation study for Germany. International Tax and Public Finance, 15(5), 620-636.

Garcia-Muniesa, J. (2018). Economic crisis and support for progressive taxation in Europe. European Societies, 21(2), 256-279.

Gimpelson, V., \& Treisman, D. (2018). Misperceiving Inequality. Economics \& Politics, $30(1), 27-54$.

Goubin, S., \& Hooghe, M. (2020). The Effect of Inequality on the Relation Between Socioeconomic Stratification and Political Trust in Europe. Social Justice Research, 33(2), 219-247.

Gross, C., Lorek, K., \& Richter, F. (2017). Attitudes towards inheritance taxation - results from a survey experiment. The Journal of Economic Inequality, 15(1), 93-112.

Guillaud, E., Olckers, M., \& Zemmour, M. (2020). Four Levers of Redistribution: The Impact of Tax and Transfer Systems on Inequality Reduction. Review of Income and Wealth, 66(2), 444-466.

Hennighausen, T., \& Heinemann, F. (2015). Don't Tax Me? Determinants of Individual Attitudes Toward Progressive Taxation. German Economic Review, 16(3), 255-289.

Hooghe, M., Dassonneville, R., \& Oser. J. (2019). Public Opinion, Turnout and Social Policy: A Comparative Analysis of Policy Congruence in European Liberal Democracies. Political Studies, 67(4), 992-1009.

Hooghe, M., Marien, S., \& De Vroome, T. (2012). The cognitive basis of trust. The relation between education, cognitive ability, and generalized and political trust. Intelligence, 40(6), 604-613.

Iversen, T., \& Goplerud, M. (2018). Redistribution Without a Median Voter: Models of Multidimensional Politics. Annual Review of Political Science, 21(1), 295-317.

Jæger, M. (2008). Does left-right orientation have a causal effect on support for redistribution? Casual analysis with cross-sectional data using instrumental variables. International Journal of Public Opinion Research, 20(3), 363-374.

Jedinger, A., \& Burger, A. (2019). The role of right-wing authoritarianism and political sophistication in shaping attitudes toward redistribution. European Journal of Social Psychology, 49(3), 560-573.

Kiewiet, D. R. \& Lewis-Beck, M.S. (2011). No 'Man' is an Island. Self-Interest, the Public Interest, and Sociotropic Voting. Critical Review, 23(3), 303-319. 
Kim, Y. (2019). How Cross-Cutting News Exposure Relates to Candidate Issue Stance Knowledge, Political Polarization, and Participation: The Moderating Role of Political Sophistication. International Journal of Public Opinion Research, 31(4), 626-648.

Kölln, A.-K. (2018). Political sophistication affects how citizens' social policy preferences respond to the economy. West European Politics, 41(1), 196-217.

Kriesi, H.-P., Grande, E., Lachat, R., Dolezal, M., Bornschier, S., \& Frey, T. (2006). Globalization and the transformation of the national political space: Six European countries compared. European Journal of Political Research, 45(6), 921-956.

Lewis-Beck, M. S., \& Nadeau, R. (2009). Obama and the Economy in 2008. PS: Political Science \& Politics, 42(3), 479-483.

Lewis-Beck, M. S., Nadeau, R., \& Foucault, M. (2013). The Compleat Economic Voter: New Theory and British Evidence. British Journal of Political Science, 43(2), 241-261.

Limberg, J. (2019). 'Tax the rich'? The financial crisis, fiscal fairness, and progressive income taxation. European Political Science Review, 11, 319-336.

Limberg, J. (2020). What's fair? Preferences for tax progressivity in the wake of the financial crisis. Journal of Public Policy, 40(2), 171-193.

Luskin, R. C. (1987). Measuring Political Sophistication. American Journal of Political Science, 31(4), 856-899.

Luskin, R. C. (1990). Explaining Political Sophistication. Political Behavior, 12(4), 331-361.

Lyon, S., Dalton, T., \& Dalton, K. (2018). Flat Versus Graduated Tax Regimes: EconomicsBased vs. Psychology-Based Explanations for Individual Preferences. Journal of Business Enquiry, 18(2), 162-175.

Mahieu, B., Geys, B., \& Heyndels, B. (2017). Fiscal Fairness as a Political Argument. Kyklos, 70(4), 622-640.

Marthaler, M. (2008) The Paradox of the Politically-Sophisticated Partisan: The French Case. West European Politics, 31(5), 937-959.

Newton, K., \& Confalonieri, M.I. (1998). Politics, Economics, Class and Taxation. In O. Borre, \& E. Scarbrough (Eds.), The Scope of Government. Oxford: Oxford University Press.

Nolan, B., Salverda, W., \& Smeeding, T. (Eds.) (2009). Oxford Handbook of Economic Inequality. Oxford: Oxford University Press.

OECD (2011). Divided We Stand: Why Inequality Keeps Rising. Paris: OECD Publishing.

OECD (2019). OECD Social and Welfare Statistics. Paris: OECD Publishing

OECD (2020). Revenue Statistics 2019. Paris: OECD Publishing. 
Piketty, T. (2019). Capital et idéologie. Paris: du Seuil.

Pitlik, H., Schwarz, G., Bechter, B., \& Brandl, B. (2011). Near Is My Shirt but Nearer Is My Skin: Ideology or Self-Interest as Determinants of Public Opinion on Fiscal Policy Issues. Kyklos, 64(2), 271-290.

Roberts, M., Hite, P., \& Bradley, C. (1994). Understanding Attitudes toward Progressive Taxation. Public Opinion Quarterly, 58(2), 165-190.

Roosma, F., Van Oorschot, W., \& Gelissen, J. (2016). A Just Distribution of Burdens? Attitudes Toward the Social Distribution of Taxes in 26 Welfare States. International Journal of Public Opinion Research, 28(3), 376-400.

Stiers, D. (2021). Political Information and Retrospective Voting. West European Politics, 44(2), 275-298.

Sumino, T. (2016). Level or Concentration? A Cross-national Analysis of Public Attitudes Towards Taxation Policies. Social Indicators Research, 129(3), 1115-1134.

Tarroux, B. (2019). The value of tax progressivity: Evidence from survey experiments. Journal of Public Economics, 179, art. 104068.

Tóth, I., \& Keller, T. (2011). Income Distributions, Inequality Perceptions and Redistributive Claims in European Societies. Amsterdam: AIAS, GINI Discussion Paper 7.

Van Der Waal, J., De Koster, W., \& van Oorschot, W. (2013). Three Worlds of Welfare Chauvinism? How Welfare Regimes Affect Support for Distributing Welfare to Immigrants in Europe. Journal of Comparative Policy Analysis: Research and Practice, 15(2), 164-181. 


\section{Appendix A: Variables in the analyses}

-Tax difference (dependent): Respondents were asked the following question: 'This question is about taxes. Imagine that a rich and a poor person each have 100 euro on which they have to pay taxes. How much of these 100 euros should each of the pay in taxes?' They could indicate their preferred level of taxation for each hypothetical person respectively as shown below:

\begin{tabular}{|l|l|l|l|l|l|l|l|l|l|l|l|}
\hline A rich person & 0 & 10 & 20 & 30 & 40 & 50 & 60 & 70 & 80 & 90 & 100 \\
\hline A poor person & 0 & 10 & 20 & 30 & 40 & 50 & 60 & 70 & 80 & 90 & 100 \\
\hline
\end{tabular}

- Sex: Sex of the respondent: $0=$ male; $1=$ female

-Age: Age of the respondent in the year of survey. Calculated as 2019 minus the year of birth of the respondent.

-Not in active labour force: Denotes respondents who are not part of the active labour force (i.e., helping family members, student/in training, retired, houseman/-wive, unfit to work).

-Income: Self-reported income of the family of the respondent, divided into seven categories: less than 1000/month; 1001-1500/month; 1501-2000/month; 2001-3000/month; 30014000/month; 4001-5000/month; more than 5000/month.

-Ideology: Respondents were asked to indicate their own ideological position on a continuum ranging from 0 (left) over 5 (centre) to 10 (right).

-Political sophistication: Index of two different variables. First, we include political interest. Respondents were asked to what extent they are interested in politics in general, and they could indicate this in a scale ranging from "not at all interested" (code 0) and "not very interested" to "somewhat interested" and "very interested" (code 3). Second, we include political knowledge, measured as the amount of correct responses to four factual questions. The questions were:

-The Belgian Parliament consists of...?

-Who is next in line to become the head of state of Belgium?

-When are local elections held in Belgium?

-Which of the following domains is a competence of the federal government? 
For each question, respondents could choose from four answer options or indicate they did not know the answer. Respondents indicating they did now know as well as missing responses are coded as wrong answers. ${ }^{14}$ This leads to a 5-point knowledge measure. For our measure of political sophistication, we rescale the knowledge variable to a 4-point scale (0-3), which we add up with the self-reported political interest to our sophistication index ranging from 0 to 6 .

Table A.1. Descriptive statistics of the variables in the analyses

\begin{tabular}{lrccc}
\hline Variable & Mean & Std. Dev. & Minimum & Maximum \\
\hline Tax difference (dependent) & 25.430 & 25.835 & -46.951 & 92.934 \\
Sex & 0.486 & 0.500 & 0 & 1 \\
Age & 52.083 & 17.311 & 18 & 85 \\
Not in active labour force & 0.416 & 0.493 & 0 & 1 \\
Income & 4.142 & 1.578 & 1 & 7 \\
Ideology & 5.298 & 2.345 & 0 & 10 \\
Political sophistication & 3.427 & 1.419 & 0 & 6
\end{tabular}

${ }^{14}$ Note, however, that coding these "don't' knows" as missing answers and excluding them from the analysis leads to substantially the same results. 


\section{Appendix B: Replication using ratio of preferred taxed for rich and poor as dependent} variable

As a robustness test, we also conducted the analyses with as dependent variable the ratio of preferred taxes, according to the following formula: ratio=(\% poor $/ \%$ rich $) * 100$. Like this, the dependent variable indicates what percentage of the taxes of the rich the respondent favours the poor to pay. The scale runs from 0 (taxes for the rich, no taxes for the poor) to 100 (same taxes for rich and poor). We exclude the respondents favouring higher taxes for the poor than for the rich, as all observations with a ratio higher than 100 are outliers. ${ }^{15}$ Note that, with this scale, the interpretation of the coefficients is opposite to that in the main text, as higher numbers on the dependent variable now indicate favouring less progressive taxes.

\footnotetext{
${ }^{15}$ Respondents favouring a $0 \%$ tax rate for both the rich and the poor person have a ratio of $100 \%$, as they favour the same tax rate for the rich and poor person. Excluding these respondents leads to the same results.
} 
Table B.1: Replication of Table 1 using ratio poor/rich as dependent variable

\begin{tabular}{lccc}
\hline & Model 1 & Model 2 & Model 3 \\
& B & B & $\begin{array}{c}\text { B } \\
(\text { s.e. })\end{array}$ \\
\hline Female & $-4.206^{*}$ & $-3.986^{*}$ & $-4.182^{*}$ \\
Age & $(1.806)$ & $(1.800)$ & $(1.799)$ \\
Not in active labour force & $-0.500^{* * *}$ & $-0.502^{* * *}$ & $-0.494^{* * *}$ \\
& $(0.066)$ & $(0.066)$ & $(0.066)$ \\
Political sophistication & -1.302 & -1.624 & -1.454 \\
& $(2.325)$ & $(2.318)$ & $(2.316)$ \\
Ideology & 0.112 & $-4.549^{* *}$ & $6.043^{* * *}$ \\
& $(0.697)$ & $(1.502)$ & $(1.820)$ \\
Income & $2.176^{* * *}$ & -1.062 & $2.146^{* * *}$ \\
Sophistication X Ideology & $(0.380)$ & $(1.000)$ & $(0.379)$ \\
& $2.441^{* * *}$ & $2.411^{* * *}$ & $7.511^{* * *}$ \\
Sophistication X income & $(0.633)$ & $(0.630)$ & $(1.570)$ \\
Constant & & $0.916^{* * *}$ & \\
& & $(0.262)$ & \\
\hline$N$ & & & $-1.440^{* * * *}$ \\
Pseudo- $R^{2}$ & $54.798^{* * *}$ & $71.601^{* * *}$ & $(0.409)$ \\
\hline
\end{tabular}

Note: Entries are unstandardized OLS coefficients, standard errors in parentheses. Significance levels: *: $\mathrm{p}<0.05$; $* *: \mathrm{p}<0.01 ; * * *: \mathrm{p}<0.001$.

Figure B.1. Replication of Figure 3 using ratio as dependent variable
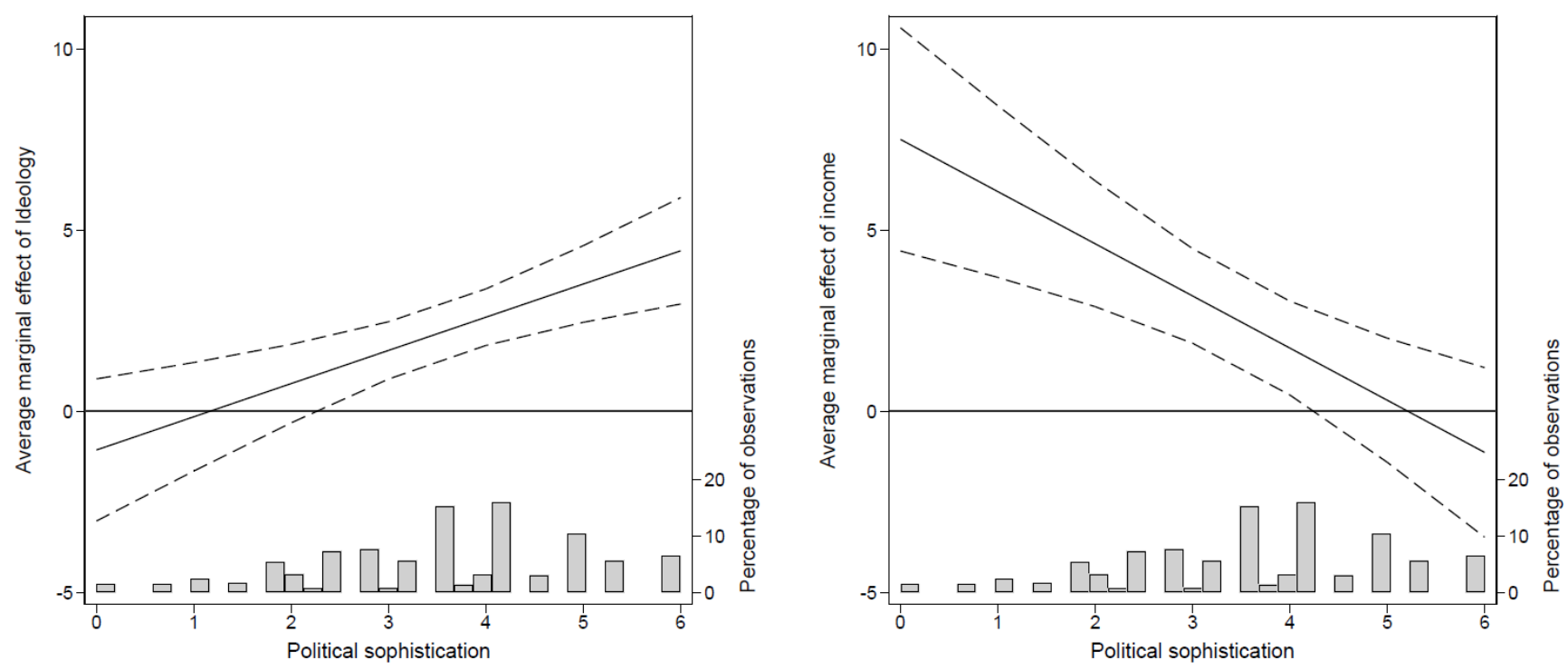

Note: Figure shows the average marginal effects of ideology (left) an income (right) on different levels of political sophistication based on the results reported in Model 2 (ideology) and Model 3 (income) in Table B.1. 


\section{Appendix C: Validating the new question}

We asked respondents to what extent they agreed with the statement that "the government should take measures to reduce differences in income" on a 5-point scale ranging from "fully disagree" over "agree nor disagree" to "fully agree". To obtain a view on the association between the answers to this and the new question, Figure G.1 shows the preferred difference in tax rate for respondents disagreeing with the statement (left side) or agreeing with the statement (right side). ${ }^{16}$

Figure G.1. Difference between preferred tax rate of a rich person and a poor person for respondents disagreeing and agreeing with government intervention respectively
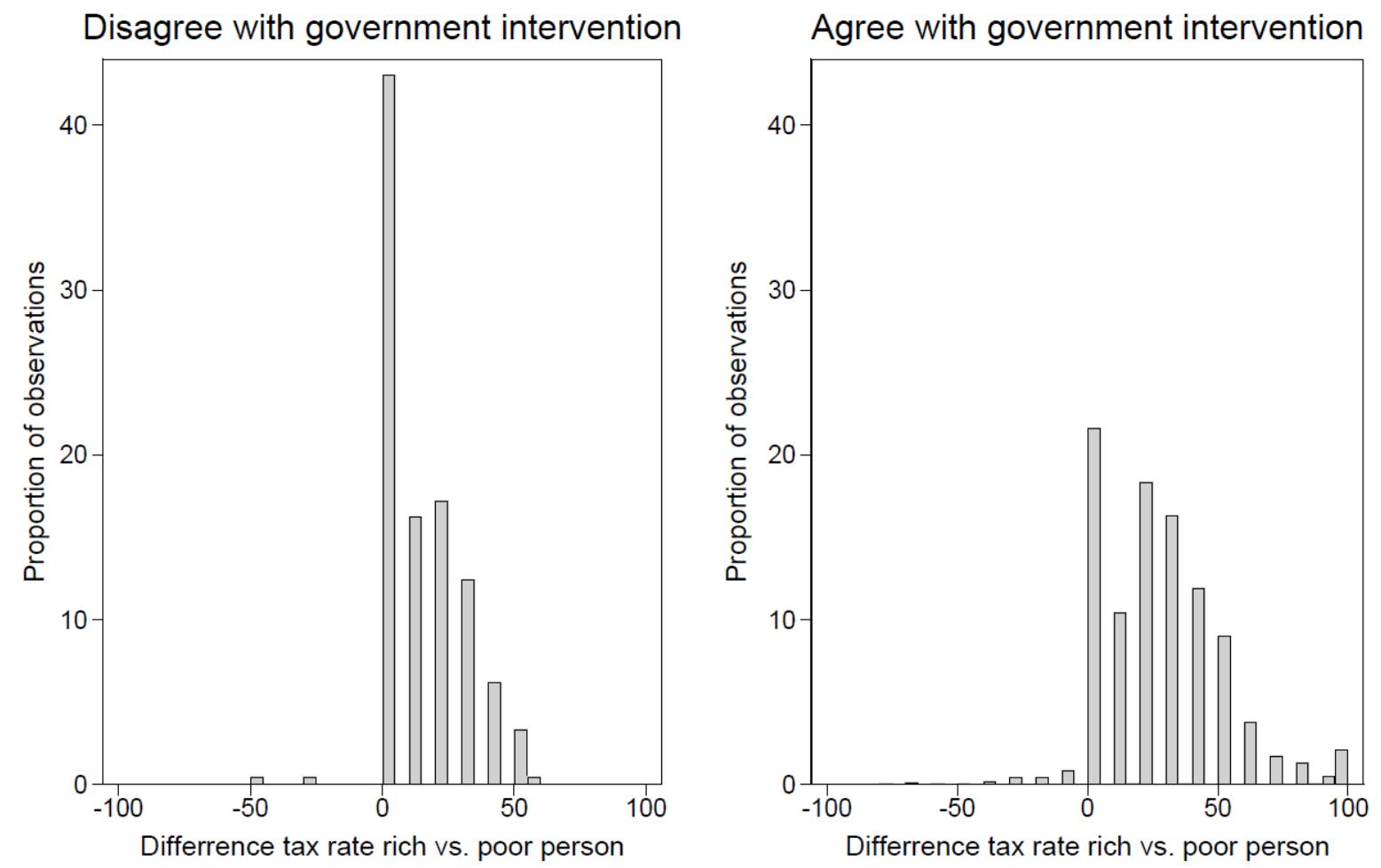

Note that the figure shows the relative proportions within each group respectively. In terms of absolute numbers, the group agreeing with the statement is substantially larger $(1,371)$ than the group disagreeing (223). 41.10\% of the respondents disagreeing with government intervention indicated the same tax rate for both hypothetical persons. Among the respondents agreeing with government intervention, this is only $21.33 \%$. Furthermore, respondents agreeing with government intervention favour, on average, a higher difference in tax rate between the poor and the rich. A difference-of-means test indicated that these respondents favour on average a

${ }^{16}$ We hence exclude the group agreeing nor disagreeing. In Appendix C, we show the distribution for this group. 
12 percentage points larger difference than the respondents not agreeing with government intervention (significant at $\mathrm{p}<0.001$ ).

Figure C.2 shows the distribution for those who agree nor disagree with government intervention.

Figure C.2. Difference between preferred tax rate of a rich person and a poor person for respondents agreeing nor disagreeing with government intervention

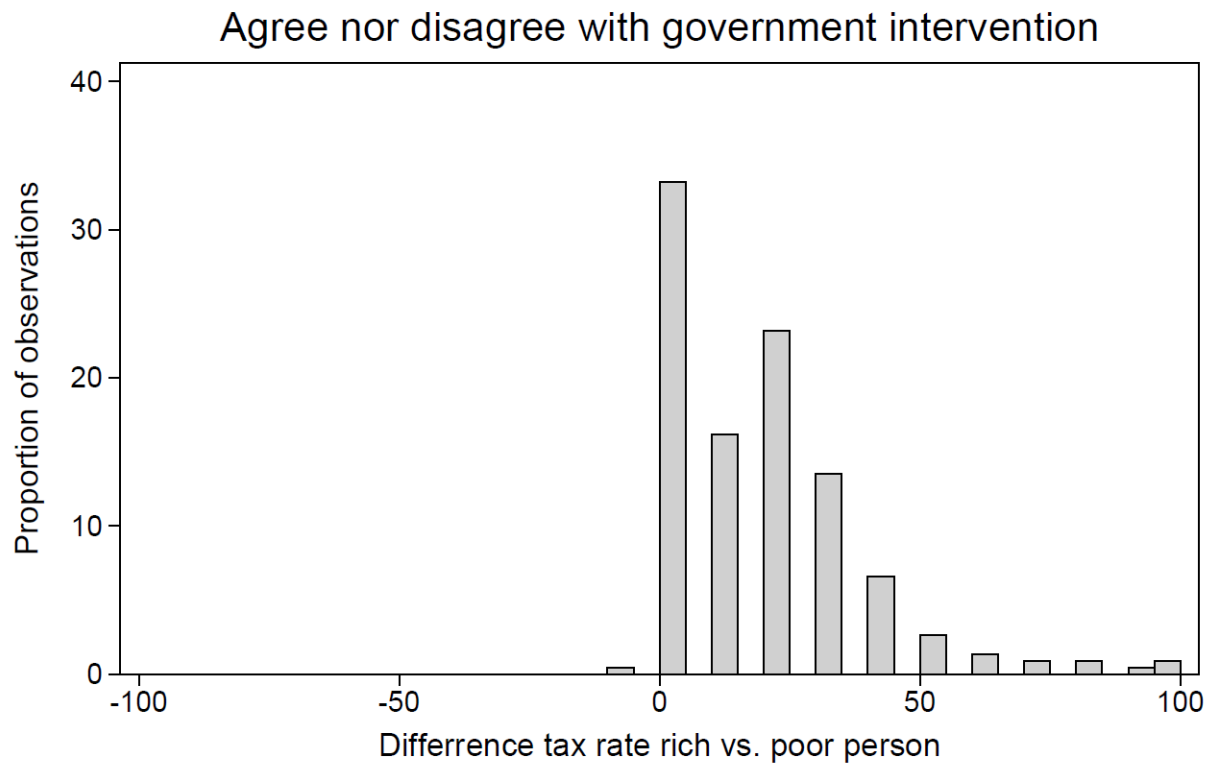




\section{Appendix D: Multilevel models including inequality in postal region respondent}

As a measure of inequality, we use the interquartile coefficient, expressing the difference between the $1^{\text {st }}$ and $3^{\text {rd }}$ quarter of all fiscal earnings in a municipality as a proportion of the median income of the inhabitants of the municipality. We calculated the coefficient to indicate the coefficient by postal region by weighting each municipality within a postal region by the number of inhabitants.

Table D.1. Explaining support for Progressive Taxes

\begin{tabular}{|c|c|c|c|}
\hline & $\begin{array}{c}\text { Model } 1 \\
\text { B } \\
\text { (s.e.) }\end{array}$ & $\begin{array}{c}\text { Model } 2 \\
\text { B } \\
\text { (s.e.) }\end{array}$ & $\begin{array}{c}\text { Model } 3 \\
\text { B } \\
\text { (s.e.) }\end{array}$ \\
\hline \multicolumn{4}{|l|}{ Individual level } \\
\hline Female & $\begin{array}{c}1.898 \\
(1.228)\end{array}$ & $\begin{array}{c}1.858 \\
(1.226)\end{array}$ & $\begin{array}{c}1.810 \\
(1.225)\end{array}$ \\
\hline Age & $\begin{array}{c}0.295^{* * * *} \\
(0.045)\end{array}$ & $\begin{array}{c}0.295^{* * *} \\
(0.045)\end{array}$ & $\begin{array}{c}0.300^{* * *} \\
(0.045)\end{array}$ \\
\hline Not in active labour force & $\begin{array}{c}2.433 \\
(1.587)\end{array}$ & $\begin{array}{c}2.418 \\
(1.585)\end{array}$ & $\begin{array}{c}2.584 \\
(1.583)\end{array}$ \\
\hline Political sophistication & $\begin{array}{l}-0.345 \\
(0.472)\end{array}$ & $\begin{array}{l}-2.807^{*} \\
(1.229)\end{array}$ & $\begin{array}{l}2.429^{*} \\
(1.022)\end{array}$ \\
\hline Ideology & $\begin{array}{c}-1.268^{* * * *} \\
(0.259)\end{array}$ & $\begin{array}{c}-1.256^{* * * *} \\
(0.259)\end{array}$ & $\begin{array}{c}0.657 \\
(0.681)\end{array}$ \\
\hline Income & $\begin{array}{l}-0.792 \\
(0.432)\end{array}$ & $\begin{array}{c}-2.918^{* *} \\
(1.071)\end{array}$ & $\begin{array}{l}-0.773 \\
(0.431)\end{array}$ \\
\hline Sophistication X ideology & & $\begin{array}{c}0.605^{*} \\
(0.279)\end{array}$ & \\
\hline Sophistication $\mathrm{X}$ income & & & $\begin{array}{c}-0.546^{* *} \\
(0.178)\end{array}$ \\
\hline Level postal region & & & \\
\hline Inequality in postal region & $\begin{array}{c}0.020 \\
(0.074)\end{array}$ & $\begin{array}{c}0.016 \\
(0.075)\end{array}$ & $\begin{array}{c}0.022 \\
(0.076)\end{array}$ \\
\hline Constant & $\begin{array}{r}15.413 \\
(8.035) \\
\end{array}$ & $\begin{array}{c}24.055^{* * *} \\
(8.988)\end{array}$ & $\begin{array}{c}5.047 \\
(8.832)\end{array}$ \\
\hline$N$ (individuals) & 1384 & 1384 & 1384 \\
\hline$N$ (postal regions) & 72 & 72 & 72 \\
\hline Variance (constant) & $\begin{array}{c}3.504 \\
(4.959)\end{array}$ & $\begin{array}{c}4.333 \\
(5.074)\end{array}$ & $\begin{array}{c}3.729 \\
(4.947)\end{array}$ \\
\hline Variance (residual) & $\begin{array}{r}498.197 \\
(19.406) \\
\end{array}$ & $\begin{array}{r}494.146 \\
(19.245) \\
\end{array}$ & $\begin{array}{l}496.310 \\
(19.325) \\
\end{array}$ \\
\hline $\begin{array}{l}A I C \\
B I C\end{array}$ & $\begin{array}{l}12552.591 \\
12604.918\end{array}$ & $\begin{array}{l}12549.899 \\
12607.459\end{array}$ & $\begin{array}{l}12545.296 \\
12602.856\end{array}$ \\
\hline
\end{tabular}


Figure D.1. Average marginal effects of ideology and income respectively at different levels of political sophistication
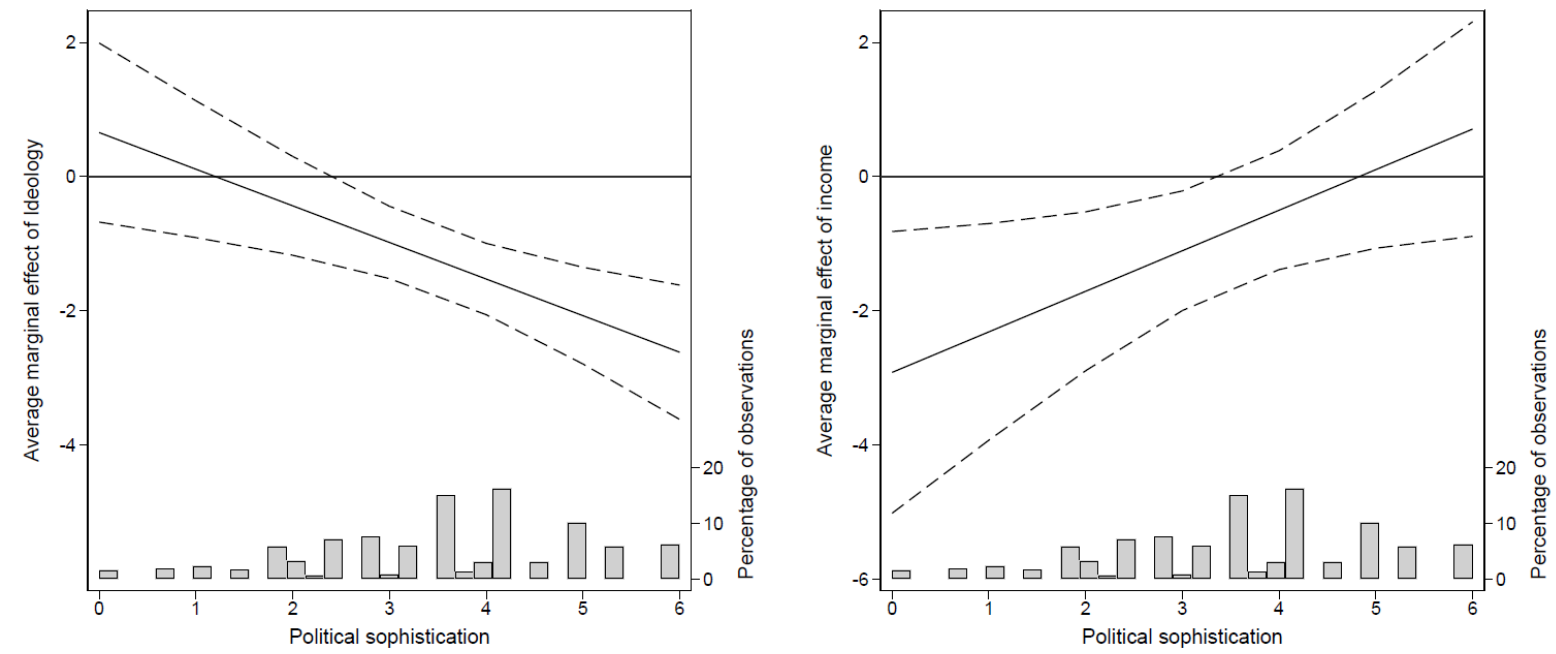

Note: Figure shows the average marginal effects of ideology (left) an income (right) on different levels of political sophistication based on the results reported in Model 2 (ideology) and Model 3 (income) in Table D.1. 
Appendix E: Results using anti-immigrant sentiments as measure of ideology

Table E.1. Explaining support for Progressive Taxes

\begin{tabular}{|c|c|c|c|}
\hline & $\begin{array}{c}\text { Model } 1 \\
\text { B } \\
\text { (s.e.) }\end{array}$ & $\begin{array}{c}\text { Model } 2 \\
\text { B } \\
\text { (s.e.) } \\
\end{array}$ & $\begin{array}{c}\text { Model } 3 \\
\text { B } \\
\text { (s.e.) } \\
\end{array}$ \\
\hline Female & $\begin{array}{c}2.082 \\
(1.220)\end{array}$ & $\begin{array}{c}2.304 \\
(1.215)\end{array}$ & $\begin{array}{c}2.016 \\
(1.218)\end{array}$ \\
\hline Age & $\begin{array}{c}0.348^{* * *} \\
(0.045)\end{array}$ & $\begin{array}{c}0.344^{* * *} \\
(0.045)\end{array}$ & $\begin{array}{c}0.344^{* * *} \\
(0.045)\end{array}$ \\
\hline Not in active labour force & $\begin{array}{c}0.109 \\
(1.576)\end{array}$ & $\begin{array}{c}0.286 \\
(1.568)\end{array}$ & $\begin{array}{c}0.149 \\
(1.573)\end{array}$ \\
\hline Political sophistication & $\begin{array}{l}-0.449 \\
(0.472)\end{array}$ & $\begin{array}{c}4.682^{* * *} \\
(1.340)\end{array}$ & $\begin{array}{c}-3.333^{* *} \\
(1.194)\end{array}$ \\
\hline Anti-immigration & $\begin{array}{l}-1.141 \\
(0.595)\end{array}$ & $\begin{array}{l}4.521^{* *} \\
(1.506)\end{array}$ & $\begin{array}{l}-1.108 \\
(0.594)\end{array}$ \\
\hline Income & $\begin{array}{c}-1.639^{* * *} \\
(0.431)\end{array}$ & $\begin{array}{c}-1.627^{* * *} \\
(0.429)\end{array}$ & $\begin{array}{c}-4.144^{* * * *} \\
(1.046)\end{array}$ \\
\hline Sophistication $\mathrm{X}$ anti-immigration & & $\begin{array}{c}-1.595^{* * * *} \\
(0.390)\end{array}$ & \\
\hline Sophistication $\mathrm{X}$ income & & & $\begin{array}{l}0.721^{* *} \\
(0.274)\end{array}$ \\
\hline Constant & $\begin{array}{c}17.141^{* * *} \\
(3.670)\end{array}$ & $\begin{array}{l}-1.651 \\
(5.869) \\
\end{array}$ & $\begin{array}{c}26.725^{* * * *} \\
(5.168) \\
\end{array}$ \\
\hline$N$ & 1573 & 1573 & 1573 \\
\hline Pseudo- $R^{2}$ & 0.072 & 0.082 & 0.076 \\
\hline
\end{tabular}


Figure E.1. Average marginal effects of income and anti-immigrant sentiments respectively at different levels of political sophistication
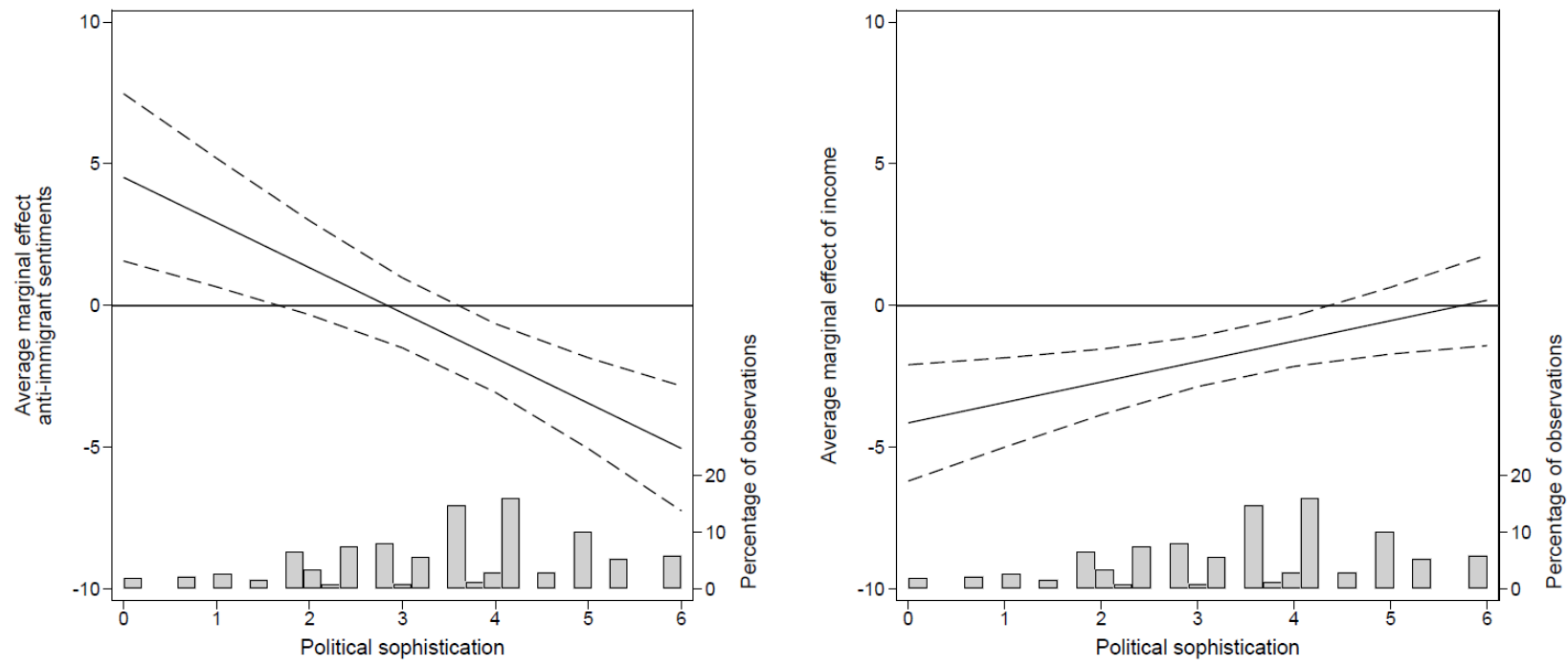

Note: Figure shows the average marginal effects of anti-immigration sentiments (left) an income (right) on different levels of political sophistication based on the results reported in Model 3 (anti-immigration sentiments) and Model 3 (income) in Table E.1. 


\section{Appendix F: Demographics of the high-income and highly sophisticated respondents}

Table F.1. Age and belonging to the high-income/highly sophisticated group

\begin{tabular}{ccc}
\hline $\begin{array}{c}\text { Highly } \\
\text { sophisticated/income } \\
\text { group }\end{array}$ & Other respondents & Difference \\
\hline 50.513 & 52.573 & $\begin{array}{c}2.060 \\
(\mathrm{p}=0.196)\end{array}$ \\
\hline
\end{tabular}

Table F.2. Cross-tab sex and belonging to the high-income/highly sophisticated group

\begin{tabular}{lccc}
\hline & $\begin{array}{c}\text { Not high income } \\
\text { high } \\
\text { sophistication }\end{array}$ & $\begin{array}{c}\text { High income } \\
\text { high } \\
\text { sophistication }\end{array}$ & Total \\
\hline \multirow{2}{*}{ Man } & 778 & 76 & 854 \\
\multirow{2}{*}{ Woman } & $(51.25 \%)$ & $(64.41 \%)$ & $(52.20)$ \\
& $(44.75 \%)$ & 42 & 782 \\
\multirow{2}{*}{ Total } & 1,518 & $(35.59 \%)$ & $(47.80 \%)$ \\
& $(100.00 \%)$ & $(100.00 \%)$ & $(100.00 \%)$ \\
\hline
\end{tabular}

The association is significant $\left(\mathrm{chi}^{2}: 7.594 ; \mathrm{p}=0.006\right)$.

Table F.3. Cross-tab educational level and belonging to the high-income/highly sophisticated group

\begin{tabular}{lccc}
\hline & $\begin{array}{c}\text { Not high income } \\
\text { high } \\
\text { sophistication }\end{array}$ & $\begin{array}{c}\text { High income } \\
\text { high } \\
\text { sophistication }\end{array}$ & Total \\
\hline \multirow{2}{*}{ Low } & 267 & 0 & 267 \\
& $(19.79 \%)$ & $(0.00 \%)$ & $(16.49 \%)$ \\
Middle & 480 & 12 & 492 \\
& $(31.98 \%)$ & $(10.17 \%)$ & $(30.39 \%)$ \\
\multirow{2}{*}{ High } & 754 & 106 & 860 \\
& $(50.23 \%)$ & $(89.83 \%)$ & $(53.12 \%)$ \\
\multirow{2}{*}{ Total } & 1,501 & 118 & 1,619 \\
& $(100.00 \%)$ & $(100.00 \%)$ & $(100.00 \%)$ \\
\hline
\end{tabular}

The association is significant $\left(\mathrm{chi}^{2}=70.504 ; \mathrm{p}<0.001\right)$. 
Table F.4. Cross-tab occupational level and belonging to the high-income/highly sophisticated group

\begin{tabular}{lccc}
\hline & $\begin{array}{c}\text { Not high income } \\
\text { high } \\
\text { sophistication }\end{array}$ & $\begin{array}{c}\text { High income } \\
\text { high } \\
\text { sophistication }\end{array}$ & Total \\
\hline Non-managerial & 528 & 27 & 555 \\
staff & $(39.76 \%)$ & $(24.77 \%)$ & $(38.62 \%)$ \\
Managerial staff & 187 & 10 & 197 \\
Low & $(14.08 \%)$ & $(9.17 \%)$ & $(13.71 \%)$ \\
management & 181 & 13 & 194 \\
Middle & $(13.63 \%)$ & $(11.93 \%)$ & $(13.50 \%)$ \\
management & 314 & 27 & 341 \\
High & $(23.64 \%)$ & $(24.77 \%)$ & $(23.73 \%)$ \\
management & 118 & 32 & 150 \\
\hline Total & $(8.89 \%)$ & $(29.36 \%)$ & $(10.44 \%)$ \\
\hline
\end{tabular}

The association is significant $\left(\mathrm{chi}^{2}=48.344 ; \mathrm{p}<0.001\right)$.

Table F.5. Cross-tab occupational level and belonging to the high-income/highly sophisticated group

\begin{tabular}{lccc}
\hline & $\begin{array}{c}\text { Not high income } \\
\text { high } \\
\text { sophistication }\end{array}$ & $\begin{array}{c}\text { High income } \\
\text { high } \\
\text { sophistication }\end{array}$ & Total \\
\hline \multirow{2}{*}{ Public sector } & 365 & 39 & 404 \\
& $(31.79 \%)$ & $(36.45 \%)$ & $(32.19 \%)$ \\
Private sector & 610 & 57 & 667 \\
\multirow{2}{*}{ Mixed } & $(53.14 \%)$ & $(53.27 \%)$ & $(53.15 \%)$ \\
\multirow{2}{*}{ Non-profit } & 67 & 3 & 70 \\
& $(5.84 \%)$ & $(2.80 \%)$ & $(5.58 \%)$ \\
\multirow{2}{*}{ Total } & 106 & 8 & 114 \\
& $(9.23 \%)$ & $(7.48 \%)$ & $(9.08 \%)$ \\
\hline
\end{tabular}

The association is not significant $\left(\mathrm{chi}^{2}=2.605 ; \mathrm{p}=0.457\right)$. 


\section{Appendix G: Ideological position and tax preference}

Figure G.1 shows the distribution of the preferred difference in taxation between a rich and a poor person for left-wing, centrist, and right-wing respondents respectively. ${ }^{17}$

Figure G.1. Difference between preferred tax rate of a rich person and a poor person by ideology of the respondent

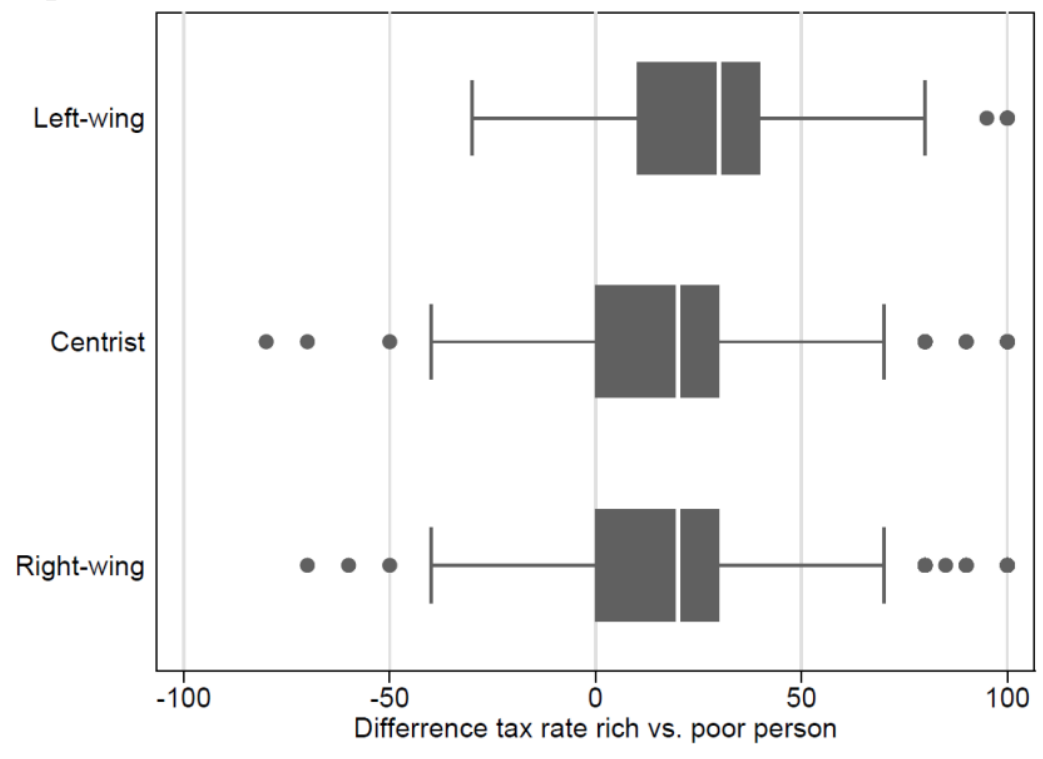

Figure G.1 shows a clear difference between left-wing respondents and all others. Left-wing respondents score higher in their preferred difference in tax rates between rich and poor people, with a difference of about 29 percentage points. Centrist and right-wing citizens, on the other hand, on average prefer a difference of about 22 points - and there do not seem to be marked differences between these two groups. Most importantly, a vast majority of all respondents favour at least some form of progressive tax rates. The difference between left- and right-wing respondents seems to be how strong the progressive character of the tax rate should be.

\footnotetext{
${ }^{17}$ Whereas in the main analysis we use the left-right continuum in its full detail, for reasons of clarity we divided respondents into three groups in order to create this figure. Left-wing respondents are those position themselves from 0 to 3 on the scale, centrist respondents are those on position 4,5 , or 6 , and right-wing respondents are those positioning themselves 7 to 10 .
} 